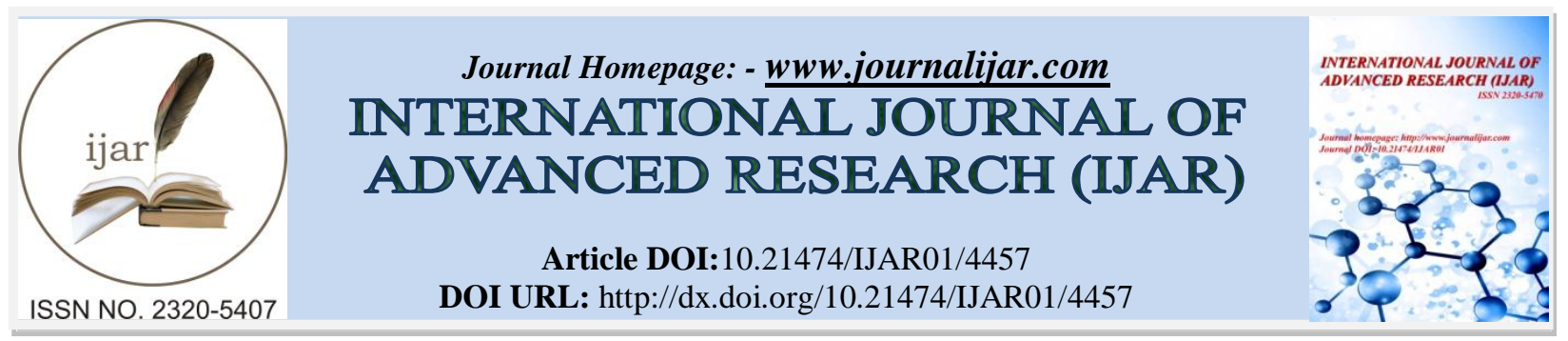

RESEARCH ARTICLE

\title{
A BEHAVIORAL ANALYSIS OF IRON AND SILICA IN IRON ORE DEPOSITS OF PARTS OF MAHAKOSHAL \& BIJAWAR REGION, MADHYA PRADESH.
}

\author{
S.V.Dhopeshwar ${ }^{1}$, Mudita Shrivastava Khare ${ }^{1}$ and Jyoti Shrivastava ${ }^{2}$. \\ 1. D'rate. of Geology and Mining, Regional Office, Govt. of Madhya Pradesh Jabalpur M.P. \\ 2. Dept. of Chemistry, Govt. Science, College, Jabalpur, M.P.
}

\section{Manuscript Info}

(..........................

Manuscript History

Received: 12 April 2017

Final Accepted: 14 May 2017

Published: June 2017

Key words:-

Iron Ore, Bijawar, Mahakoshal, IBM, $\mathrm{Fe}_{2} \mathrm{O}_{3} / \mathrm{SiO}_{2}$ factor

\section{Abstract}

Minerals play a key role in the development of any country. The deposition of mineral resources, conservation and optimal utilization for industry has always been a burning issue worldwide. Looking into the vital role of minerals in the development of any state, country and the need for proper utilization, it has now become mandatory to explore, to extract new sources of minerals which could be utilized for better production and prove beneficial for the industry.

Madhya Pradesh is endowed with mineral resources. The richness of this state in minerals namely iron-ore, manganese, limestone, bauxite, rock phosphate, dolomite etc and its fertility behavior, has triggered the search for new potential areas for production of good quality ore. In this paper, an attempt has been made to study behavioral analysis of iron and silica in iron ore deposits of some areas of Bijawar and Mahakoshal regions of M.P. state. In all, samples of 8 areas of Bijawar and Mahakoshal are specified, wherein deposits of iron-ores are analysed, interpreted chemically as well as geologically. The quality of the ore is deduced and graded as per the specifications of IBM standard. A comparative analysis of iron-ore deposits of both Bijawar and Mahakoshal region reveals that iron ore deposits in Bijawar region could be more likely opted for making quality steel of market value but use of Bijawar's iron ores can act as a sweetener to upgrade the uniformly low grade iron ores of Mahakoshal region.

Copy Right, IJAR, 2017,. All rights reserved.

\section{Introduction:-}

Madhya Pradesh (M.P) is endowed with vast natural resources. Minerals are one of the most important commodities in the growth engine of the state. There are many facets in the stages of identifying potential terrain. In this study, emphasis is laid on the chemical characterization and geological behavior of Iron ore deposits in Mahakoshal and Bijawar region. Iron is the fourth most abundant metallic element in the earth's crust. Iron is a chemical element with symbol Fe (from latin: ferrum, ultimately from ferre to bear carry) and atomic no is 26 . It is a metal in the first transition series. The most important naturally occurring iron ore minerals are oxides: magnetite and hematite, the hydrated oxides: goethite (Limonite). In Karri formation of Bijawar group, hematite is found in form of lumps and boulders mostly as float ore, spread on surface and intermixed with ferruginous shale and quartzite. In Mahakoshal group, iron ore is found as hematite in BIF (Banded Hematite Quartzite/Banded Hematite Jasperite), blue dust below $\mathrm{BIF}$ and is at times mixed with clay. 
Iron ores occur in deposits of all geological ages, but most of the world's supply is obtained from Proterozoic and Archean rocks.

\section{The Principal type of iron ore deposits are:-}

i) Bedded ores - Sometimes metamorphic

ii) Igneous segregations.

iii) Complex metamorphic deposits.

iv) Vein deposits

v) Superficial residue, resulting from weathering

vi) Goethite or bog ore.

World resources of iron ore in U.S. is estimated about 27 billion tons of iron. World resources are estimated to be greater than 800 billion tons of crude ore containing more than 230 billion ton of iron. Estimated iron ore production in million metric tons for 2015-16 according to U.S. Geological Survey.

Table 1:- Iron Ore Production.

\begin{tabular}{|c|c|c|c|}
\hline S. No & Country & Production & Remark \\
\hline 1 & China & 1500 & \multirow{14}{*}{$\begin{array}{l}* \text { The mine production estimates } \\
\text { for China are based on crude ore. }\end{array}$} \\
\hline 2 & Australia & 660 & \\
\hline 3 & Brazil & 320 & \\
\hline 4 & India & 150 & \\
\hline 5 & Russia & 105 & \\
\hline 6 & Ukraine & 82 & \\
\hline 7 & South Africa & 78 & \\
\hline 8 & U.S. & 58 & \\
\hline 9 & Iran & 45 & \\
\hline 10 & Canada & 41 & \\
\hline 11 & Sweden & 26 & \\
\hline 12 & Kazakhstan & 26 & \\
\hline \multirow[t]{2}{*}{13} & Other countries & 131 & \\
\hline & Total World Production & 3220 & \\
\hline
\end{tabular}

\section{Methodology:-}

For the analysis of Fe-ore in the samples of both the study areas, (Bijawar and Mahakoshal regions), following procedure was adopted.

Crushed fine powder of sample is weighed and moistured with water and was covered with watch glass. Then 15$20 \mathrm{ml}$ of dil. $\mathrm{HCl}$ and few drops of conc. $\mathrm{HNO}_{3}$ is added slowly, digested on a hot plate at low temperature. The beaker is removed from the hot plate, the watch glass is rinsed thoroughly and solution is again boiled. Now, the solution is allowed to cool, $15 \mathrm{ml}$ dilute $\mathrm{HCl}$ is added. The volume is made upto $250 \mathrm{ml}$. The solution is again heated and filtered.

The residue obtained on filter paper contains Acid Insoluble part $\mathrm{SiO}_{2}$ (A.I.) which is dried and ignited in a porcelain crucible at $900^{\circ}-1000^{\circ} \mathrm{c}$. The residue is cooled and weighed.

Loss of wt. in grams
A.I. $\%$
$=$

$$
\text { Wt. of samples }
$$

The filtrate obtained contains many types of oxides, $\mathrm{Al}_{2} \mathrm{O}_{3}, \mathrm{Fe}_{2} \mathrm{O}_{3} .1$ to $2 \mathrm{gm}$ of $\mathrm{NH}_{4} \mathrm{cl}$ is added to the filtrate and heated to boiling. The precipitate so obtained is filtered, residue contains $\mathrm{Fe}_{2} \mathrm{O}_{3}$ and $\mathrm{Al}_{2} \mathrm{O}_{3}$. The residue is ignited $\left(900^{\circ} \mathrm{c}-1000^{\circ} \mathrm{c}\right)$ and weighed. This gives the total value of $\mathrm{Fe}_{2} \mathrm{O}_{3}\left(\mathrm{Fe}_{2} \mathrm{O}_{3}+\mathrm{Al}_{2} \mathrm{O}_{3}\right)$. This ash is then treated with Conc. $\mathrm{HNO}_{3}, \mathrm{HgCl}_{2}$, acid solution, $\mathrm{SnCl}_{4}$ and titrated with $\mathrm{K}_{2} \mathrm{Cr}_{2} \mathrm{O}_{7}$ solution. This gives direct percentage of $\mathrm{Fe}_{2} \mathrm{O}_{3}$ and $\mathrm{Al}_{2} \mathrm{O}_{3}$. 


\section{Geographical setting:-}

Location and Extent of the study Area:-

M.P lies on the central part of Indian subcontinent. It is flourished with iron ore deposits. The iron ores occurs mostly in the rock formations of Mahakoshal and Bijawar group.

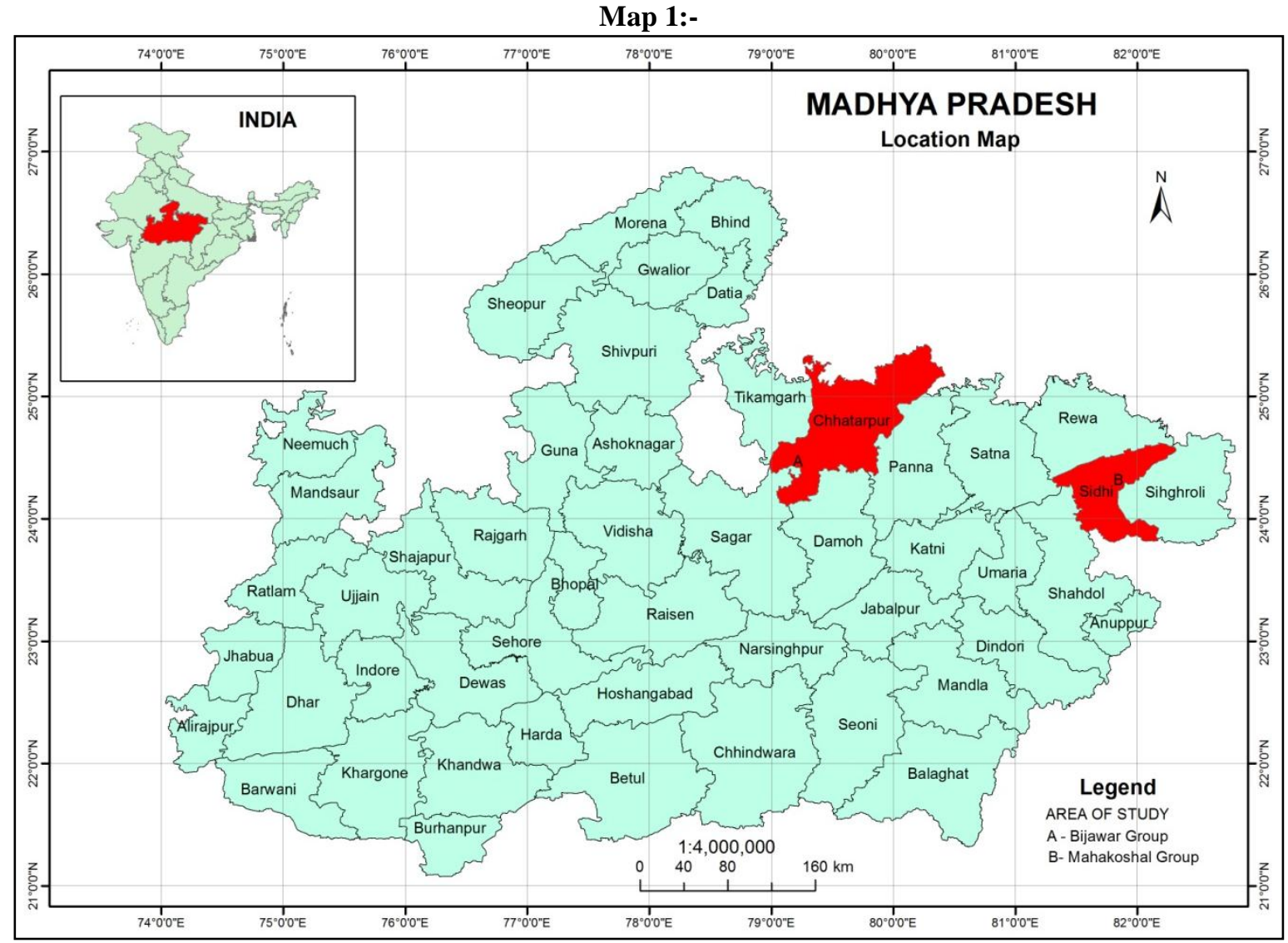

The extent of occurrence of Mahakoshal group lies in an ENE-WSE trending linear belt which occurs from Jabalpur to Sidhi district. The portions of Sidhi and Singrauli districts constitute the parts of study area of Mahakoshal group. The area is bounded by latitude $24^{\circ} 15^{\prime}-24^{\circ} 30^{\prime} \mathrm{N}$ and longitude $81^{\circ} 30^{\prime}-82^{\circ} 15^{\prime} \mathrm{E}$ and encompassed in Survey of India toposheet no. 63L/3, $63 \mathrm{H} / 11,15$. Bijawar group is limited to its type area and surroundings and the study area lies in parts of Chhatarpur, Sagar and Damoh districts of M.P. The region is owned with thick forest cover and content with moderate to poor road network. The National Highway No-82 passes through the area. The State Highways connect it with Damoh and Tikamgarh. Tikamgarh is about $130 \mathrm{Km}$. Sagar and Damoh are about $100 \mathrm{Km}$. and Chhatarpur.The Surveyed area encompasses parts of Damoh, Sagar and Chhatarpur districts and covered between latitudes: $24^{0} 15^{\prime}-24^{0} 45^{\prime}$ and longitudes: $79^{0} 0^{\prime}-79^{\circ} 45^{\prime}$. The area is categorized by undulatory terrain and marked by high hills ranges and valleys in south and mounds and plains in its north. The general height of the terrain is about 400 meters above MSL. However, central southern part of the area is traversed by Panna hill range. The range stands 100 meters above from the surroundings and more than 500 meters from the MSL. The hilly portion gradually lowers down and converges in to the alluvial plains in the north and west. The regional slope is towards west to south west the hill range acts as a water divide. Therefore, local slopes are mostly in NW or SE directions. The highest peak is in the north of Banki. The regional drainage is controlled by Ken and Dhasan river system. The other important rivers are Barana, Sukker and Bihar rivers (Map 1).

\section{Climate:-}

The climate of the area is subtropical and is characterized by general dryness except during the south west monsoon and very hot summer. The winter season is generally coldfrom mid. December to January, which is the coolest 
period, where mercury drops about $5^{0} \mathrm{C}$. The summers are quite hot here; temperature shoots up $45^{\circ} \mathrm{C}$ in May and June. The forest capped hilly terrain receives higher rains as compared to plains.

\section{Objectives:-}

As on availability of the facts and related literature the following objectives are made for this study:-

1. To analyze and infer the variations of $\mathrm{Fe}_{2} \mathrm{O}_{3}$ and Silica of iron ore deposits of study area, correlate with chemical and geological behavior.

2. An attempt to determine the factor for identifying the end use of ore, and thereafter classify them on the basis of grade as per specification made by IBM 2014.

3. Compare the iron ore deposit of parts of Mahakoshal and Bijawar region for beneficiation/up gradation of ore for its industrial utility and mineral conservation/ optimal utilization.

\section{Geology of the Study Area:-}

Bijawar Region:-

Bundelkhand granite gneiss complex forms the basement. It is unconformably overlain by Bijawar group of rocks. Kawar volcanics and Malehra chert breccia formation constitute the oldest Bijawar entity. They are overlain by Bajno dolomite formation. Darguwan intrusives is placed between Bajno dolomite and Karri Ferruginous Formation and seems like sill like body emplaced within Bajno dolomites. They are basic flows, which later on, undergone some degree of metamorphism and therefore seem to be amphobolitic. Karri ferruginous formation consists of ferruginous shales, sandstones, quartzites and breccia and contains nodules, concretions, and chunks of hematite. This is underlain, near Hirapur, by Hirapur Phosphorite horizons. The lithounits of Vindhyan super group lie over Bijawars. The arenaceous and cherty limestone, grit and clay of Lameta rest over Vindhyans. It is overlain by basaltic lava flows of Deccan Trap.

The generalized geological set of the area is summarized below -

Table 2:- Age and Stratigraphical Status of study Area.

\begin{tabular}{|c|c|c|c|}
\hline Age & \multicolumn{2}{|c|}{ Stratigraphical Status } & Lithounits \\
\hline \multicolumn{3}{|l|}{ Quaternary } & $\begin{array}{l}\text { Soil and Alluvium } \\
\text { Laterite }\end{array}$ \\
\hline $\begin{array}{l}\text { Upper Cretaceous to } \\
\text { Paleocene }\end{array}$ & \multicolumn{2}{|l|}{ Deccan Trap } & Basaltic lava flows with intertrappeans \\
\hline Cretaceous & \multicolumn{2}{|l|}{ Lameta Group } & Sandstone, limestone \\
\hline $\begin{array}{ll}\text { Meso } \\
\text { Proterozoic }\end{array}$ & \multicolumn{2}{|c|}{ Vindhyan Super group } & $\begin{array}{l}\text { Sandstone, quartzite, shales, conglomerates, } \\
\text { porcellanites, limestone }\end{array}$ \\
\hline \multirow[t]{6}{*}{ Palaeo- Proterozoic } & \multicolumn{2}{|l|}{ Intrusives } & Quartz vein, basic dykes \\
\hline & \multirow[t]{5}{*}{ Bijawar Group } & $\begin{array}{l}\text { Karri ferruginous } \\
\text { formation }\end{array}$ & $\begin{array}{l}\text { Ferruginous shale, sandstone, quartzite, chert } \\
\text { breccia }\end{array}$ \\
\hline & & Hirapur Phosphorite $\mathrm{F}$ & rmation \\
\hline & & $\begin{array}{l}\text { Darguwan Intrusive } \\
\text { Formation }\end{array}$ & Basic volcanic flows \\
\hline & & Bajna dolomite & Dolomites \\
\hline & & $\begin{array}{l}\text { Malehra chert } \\
\text { Breccia formation }\end{array}$ & Chert, Chert breccia \\
\hline Archaean & \multicolumn{2}{|c|}{ Bundelkhand Granite Gneiss Complex } & $\begin{array}{l}\text { Quartz reefs/basic dykes, Granites, } \\
\text { Granite and gneisses, Migmatites. }\end{array}$ \\
\hline
\end{tabular}


Map 2:-

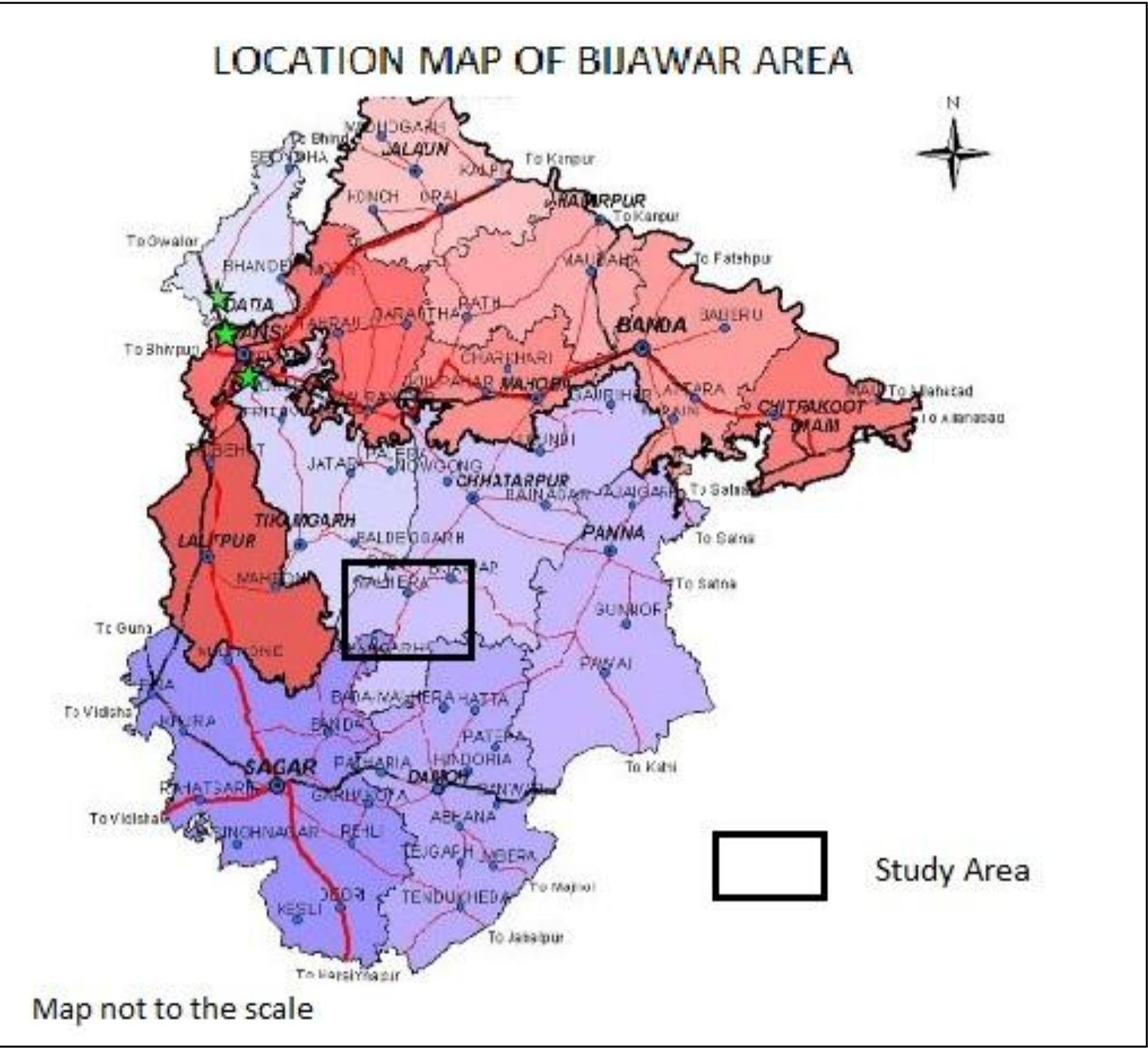

The Survey area comprises parts of Sagar, Chhatarpur and Damoh districts. (Map 2) The important patches are briefed below-

1. Siddai - Murar Area: It is located at about $4 \mathrm{~km}$ southwest of Bajna Village in the Survey of India toposheet No. $54 \mathrm{P} / 7$. The entire area lies under the protected forest cover. The general alignment of the lithounits is in the NE-SW direction. The maximum length is about $2 \mathrm{~km}$, maximum width is around $500 \mathrm{M}$ and the thickness is about $10 \mathrm{M}$ and was observed from top of the hillock to up to the road cutting. Here, alternate bands of hematite and quartzites are present with ferruginous shales and quartzite surroundings.

2. Nayakhera Area: The area is situated at about $3 \mathrm{~km} \mathrm{NW}$ of Bhimkund and can be approached from BhimkundNayakhera Pipariya road. It is covered in survey of India toposheet No. 54 P/7. The area is close to Kanjra Village and entirely lies within forest premises. In the area, hematite nodules are within karri shales, breccia and quartzite. Here, big chunks of hematite were seen around and over the hillock. The area is about $1 \mathrm{sq} . \mathrm{km}$.

3. Palda - Thakurpura Area: The area is situated in $2 \mathrm{~km}$ south of Thakurpura and is covered in parts of survey of India toposheet No. $54 \mathrm{P} / 7$ and 3. The area comes under the protected forest cover. The maximum length is about $2 \mathrm{~km}$, where as the maximum width is about $400 \mathrm{M}$ and thickness of float ore horizon is about $2 \mathrm{M}$.

4. Chopra Area: The area is situated at about $5 \mathrm{~km}$ NE of Bajna on the eastern side of Bajna - Bijawar road and covered in survey of India toposheet No. 54 P/7. The area comprises of forest capped NE-SW trending hills. The laterites are reddish brown to dark brown, hard and pisolitic to massive in nature. 
5. Bineda Area: The area is situated at about $5 \mathrm{~km} \mathrm{SSE}$ of Dhanguwan and west of Bineda village and covered in survey of India toposheet No. 54 P/3. The entire area comes under the Dalipur reserved forest. Here, the BIF has alternate dark ferruginous and grey siliceous bands.

6. Kalidhar: The area is situated at about $4 \mathrm{~km} \mathrm{SE}$ of Hirapur, near Kalidhar river, and covered in survey of India toposheet No. $54 \mathrm{P} / 3$. The entire area lies under the protected forest cover. Various linear depressions (due to non-perennial streams) between the hillocks composed large chunks of hematite. All the hills are entirely capped by laterites, in which concretions and nodules of hematite were seen.

7. Imiliya Area: The area is situated around village Imiliya, tehsil Bijawar and is at about $4 \mathrm{~km} \mathrm{SSW} \mathrm{of} \mathrm{Bijawar}$ on Bijawar Bajna metalled road. The area contains hematite nodules and boulders.

8. Dilari Area: The area is situated in the west of Dilari and covered in Survey of India toposheet No. 54 P/10. The area is part of Dilari reserved forest. Here, distinct ferruginous bands were seen in Vindhyan quartzites. Here, the ore is principally goethite which is lateritized.

\section{Mahakoshal Region:-}

The surveyed area lies in parts of Sidhi and Singrauli districts where, iron are bearing patches occur. The iron ores of Sidhi are well-known for more than as century. The area is located in the eastern extremity of the state. It is well commended by roads with neighboring Rewa district (M.P.).The surveyed area lies in the south and south west of Sidhi and Cover parts of Sidhi, Majholi and Churhat tehsil of Sidhi district and Deosar tehsil of Singrauli district. The geographical indices of surveyed areas are found $24^{\circ} 15^{\prime}-24^{0} 30^{\prime} \mathrm{N}$ latitudes and $81^{\circ} 30^{\prime}-82^{0}-15^{\prime} \mathrm{E}$ longitudes.(Map 3)

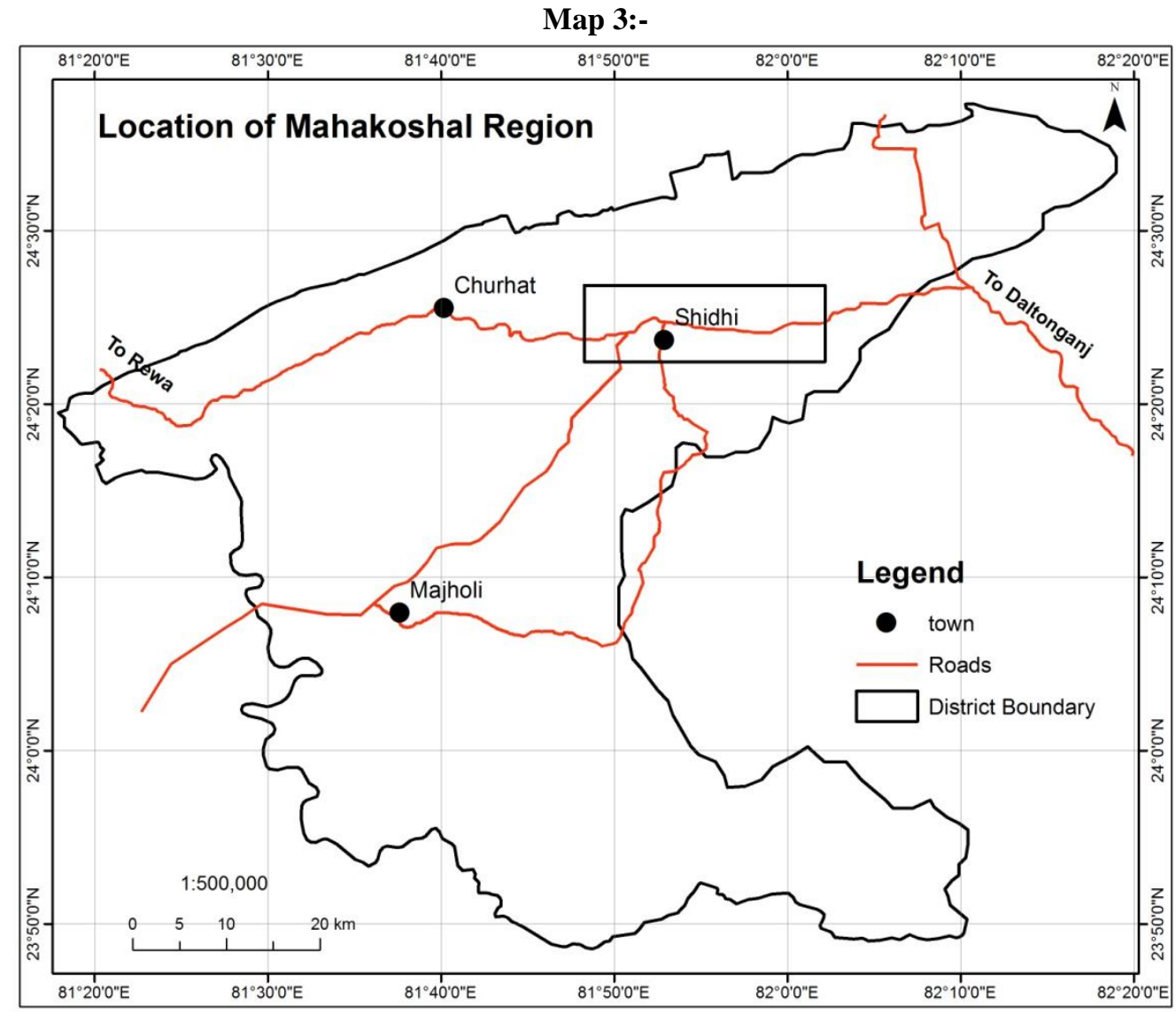

\section{Location Map of Mahakoshal Region:-}

The regional geology of the area is as wide spectrum ranging from Archaean to cretaceous formations. This part of study area exhibit wide and varied lithological characteristic and covers vast span from Archaean gneisses and schists to early- Proterozoic to middle Proterozoic to mid up to Proterozoic to recent alluvial deposits. The Archeans are represented by granites gneisses, schists and intrusive quartz veins and amphibolites. They occupy central part of 
the area around Sidhi and form the basement for overlying litho-groups. The generalized geological set up is as given below:

Table 3:- Age and Stratigraphical Status of study area.

\begin{tabular}{|l|l|l|}
\hline Age & Formation & Lithounits \\
\hline Recent to sub recent & Quaternary & Alluvial soil \\
\hline Up to Mid Proterozoic & Vindhyan Super group & Shale, sandstone, porcellanites, quartzite \\
\hline Mid Proterozoic & Jungel Group & Sandy shale, sandstone \\
\hline \multirow{2}{*}{ Palaeo-Proterozoic } & Intrusives & Quartz veins, aplite, pegmatite, basic dykes \\
\cline { 2 - 3 } & Mahakoshal Group & BIF(BHQ/BHJ),Metabasics and tuffs, Quartzite, Phyllite \\
\hline Archaean & Quartz vein, amphibolites, Granites gneisses, schist \\
\hline
\end{tabular}

The important iron ore beaming localities are briefed below:-

1. Kochita Area (63 L/3): The ore is Principally BHQ. The area is situated 2 km; the width is about $100 \mathrm{M}$ and the average height is $20 \mathrm{M}$.

2. Jhoko Area (63 L/3): Mostly BHQ. The area is WSW of Jhokho village. The length is about $1 \mathrm{~km}$, width is $150 \mathrm{M}$ and the height is about $20 \mathrm{M}$.

3. Bhainsahiya - Tarka Area (63 L/3): The ore is BHJ. The length is about $2 \mathrm{~km}$, width is $50 \mathrm{M}$ and height is 5 M.

4. Kosomhar Area 63 H/11): The ore is BHQ. The area is situated in the south of Kosomhar village. It is in form of NE-SW trending hill. Its dimensions are: length $1 \mathrm{~km} \chi$ width $200 \mathrm{M} \chi$ height $20 \mathrm{M}$.

5. Charki Area (63 H/11): The ore is lumpy, nodular and within cherty brecciated quartzite. Its dimensions are: length $800 \mathrm{M} \chi$ width $50 \mathrm{M} \chi$ height $10 \mathrm{M}$.

6. Umreha Area (63 H/11): The ore is BHQ and flanked by phyllites in the hill slopes. The hematite is mostly micaceous. The area is in the south of Umreha village. The gradational change from BHQ to quartzite is also suspected in the area. This may be due to swelling of quartzite fraction in the BIF. Its dimensions are $1 \mathrm{~km} \chi$ width $20 \mathrm{M} \chi$ height $20 \mathrm{M}$.

7. Khaddi - Jamuniha Area: The ore is lumpy hematite within quartzite. It is in form of chain of isolated mounds, trend in NE-SW and surrounded by phyllites. Their total dimensions are: length $1 \mathrm{~km} \chi$ width $100 \mathrm{M} \chi$ height $5 \mathrm{M}$. These are within phyllites and the weathering of phyllites has resulted in the formation of red ochre and clay.

8. Nimoura area:Thearea lies about $1 \mathrm{~km} \mathrm{SSW}$ of the village. This is in the form of ENE-WSE trending hill. There are two hills which are apart by $200 \mathrm{M}$ of plain land. These hills comprises of BHQ. The some length of both hills is about $1 \mathrm{Km}$, width $50 \mathrm{M}$ and the height is about $5 \mathrm{M}$.

\section{Discussion and Interpretation:-}

The present study is majorly focused to estimate iron, silica and alumina contents in form of their oxides in nearly 8 areas of Bijawar and Mahakoshal region to accomplish the goal of better productivity, good utility and fuel consumption.

\section{Bijawar Region:-}

\section{Chemical Analysis and Interpretation:-}

In Bijawar region the 8 study areas examined are Sidhai-Murar, Nayakhera, Palda - Thakurpura, Chopra, Bineda, Kalidhar, Limiliya and Dilari areas. The chemical analysis of these areas are displayed in table 4.

Table 4:-Chemical Analysis of Iron ore samples of Bijawar Region

\begin{tabular}{|c|c|c|c|c|c|c|}
\hline S. No & Name of the Area & Sample code & $\mathrm{SiO}_{2}$ & $\mathrm{Fe}_{2} \mathrm{O}_{3}$ & $\mathrm{Fe} \%$ & $\mathrm{Al}_{2} \mathrm{O}_{3}$ \\
\hline \multirow[t]{5}{*}{1} & Siddai-Murar Area & DRD-1 & 12.24 & 80.80 & 56.51 & 1.50 \\
\hline & & DRD-2 & 0.86 & 96.70 & 67.44 & 1.34 \\
\hline & & DRD-3 & 24.8 & 66.70 & 46.65 & 3.52 \\
\hline & & RH-1 & 10.6 & 76.75 & 53.68 & 7.55 \\
\hline & & Average & 11.99 & 80.24 & 56.12 & 3.48 \\
\hline \multirow[t]{3}{*}{2} & Nayakhera Area & Kaj-1 & 4.12 & 93.50 & 65.40 & 0.80 \\
\hline & & Kaj-2 & 7.76 & 77.00 & 53.86 & 13.00 \\
\hline & & Kaj-3 & 7.16 & 84.50 & 59.10 & 4.80 \\
\hline
\end{tabular}




\begin{tabular}{|c|c|c|c|c|c|c|}
\hline & & Kaj-4 & 1.30 & 95.10 & 66.52 & 1.10 \\
\hline & & Kaj-5 & 4.26 & 92.40 & 64.63 & 0.80 \\
\hline & & Average & 4.92 & 88.50 & 61.90 & 4.10 \\
\hline 3 & Palda Thakurpura Area & ThP-1 & 25.58 & 69.90 & 48.89 & 1.50 \\
\hline \multirow{2}{*}{3} & & ThP-7 & 3.84 & 91.50 & 64.00 & 1.50 \\
\hline & & ThP-8 & 20.94 & 72.25 & 50.53 & 6.50 \\
\hline & & Average & 16.79 & $\mathbf{7 7 . 8 8}$ & $\mathbf{5 4 . 4 7}$ & 3.17 \\
\hline \multirow[t]{5}{*}{4} & Chopra Area & L1 & 21.20 & 66.20 & 46.30 & Traces \\
\hline & & L2 & 10.26 & 84.32 & 58.98 & Traces \\
\hline & & L3 & 11.74 & 82.00 & 57.35 & Traces \\
\hline & & L5 & 7.28 & 86.16 & 60.26 & Traces \\
\hline & & Average & 12.62 & 79.62 & 55.72 & Traces \\
\hline \multirow[t]{6}{*}{5} & Bineda Area & $\mathrm{Bd}-2$ & 2.38 & 91.40 & 63.93 & 3.45 \\
\hline & & Bd-3 & 44.78 & 48.25 & 33.75 & 3.40 \\
\hline & & Bd-4 & 14.20 & 79.10 & 55.33 & 3.40 \\
\hline & & Bd-6 & 41.76 & 52.50 & 36.72 & 2.20 \\
\hline & & $\mathrm{Bd}-8$ & 15.04 & 76.80 & 53.72 & 5.40 \\
\hline & & Average & 23.63 & 69.61 & 48.69 & 3.57 \\
\hline \multirow[t]{4}{*}{6} & Kalidhar Area & Thp-5 & 23.46 & 66.75 & 46.69 & 4.71 \\
\hline & & Thp-6 & 13.56 & 65.70 & 45.95 & 12.60 \\
\hline & & $\mathrm{C}-1$ & 14.60 & 72.25 & 50.53 & 6.50 \\
\hline & & Average & 17.20 & 68.23 & 47.72 & 7.93 \\
\hline \multirow[t]{5}{*}{7} & Limiliya Area & Lml-1 & 1.44 & 94.00 & 65.75 & 0.80 \\
\hline & & Lml-2 & 3.88 & 84.00 & 58.75 & 6.95 \\
\hline & & Lml-3 & 18.16 & 88.80 & 41.13 & 9.60 \\
\hline & & Lml-4 & 4.30 & 81.60 & 57.07 & 3.10 \\
\hline & & Average & 6.94 & 87.10 & 60.92 & 5.11 \\
\hline \multirow[t]{4}{*}{8} & Dilari Area & $\mathrm{D}-1 \mathrm{~A}$ & 14.00 & 79.50 & 55.60 & 3.90 \\
\hline & & D-1B & 33.08 & 58.50 & 40.91 & 5.10 \\
\hline & & D-4L & 20.84 & 52.40 & 36.65 & 9.20 \\
\hline & & Average & 22.64 & 63.47 & 44.39 & 6.07 \\
\hline
\end{tabular}


Diagrammatic representation of chemical analysis of Iron ore samples of Bijawar Region.

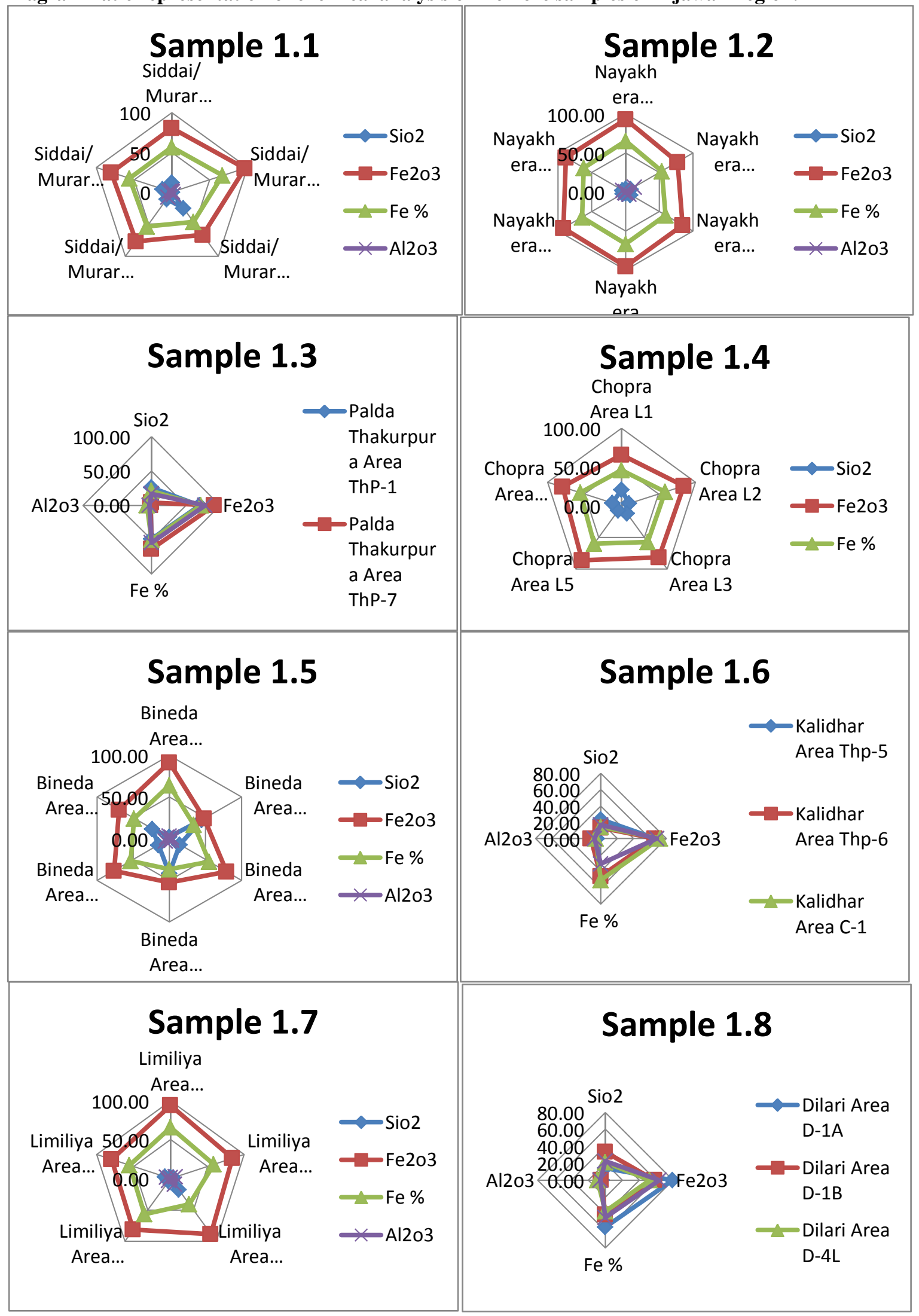


The results displayed in the Table 4 clearly depicts that amongst the 8 study areas and 28 samples analysed for Bijawar region sampl (DRD-2) of Siddai - Murar area is found to contain the highest \% of Fe-content Viz. $67.44 \%$ accompanied by $0.86 \% \mathrm{SiO}_{2}$ content and $1.34 \% \mathrm{Al}_{2} \mathrm{O}_{3}$ content. This is followed by sample 4 of Nayakhera area with $66.52 \% \mathrm{Fe}, 1.30 \% \mathrm{SiO}_{2}, 1.10 \% \mathrm{Al}_{2} \mathrm{O}_{3}$, Sample 1 of Imiliya area with $65.75 \% \mathrm{Fe}, 1.44 \% \mathrm{SiO}_{2}$, and $0.80 \%$ $\mathrm{Al}_{2} \mathrm{O}_{3}$, Sample Kaji-1 of Nayakhera area contains $65.40 \% \mathrm{Fe}, 4.12 \% \mathrm{Sio}_{2}$ and $0.80 \% \mathrm{Al}_{2} \mathrm{O}_{3}$ content.

On careful examination of the above mentioned results shown in table 4 and following the prescribed norms implemented by IBM, it has been deduced that in the Bijawar region, predominantly 4 samples of Siddai - Murar, Nayakhera, Imiliya areas are found to be of high grade quality, fulfilling the requirements of making good quality steel. One of the samples of Nayakhera area shows variation in $\mathrm{SiO}_{2}$ content, but this could be beneficiated and treated accordingly.

On the other hand, sample 5 of Nayakhera area was found to contain Fe-content $64.63 \%$ with $4.26 \% \mathrm{Sio}_{2}$ and $0.80 \%$ $\mathrm{Al}_{2} \mathrm{O}_{3}$ sample 2 of Palda-Thakurpura area contained $64.0 \%$ Fe content with $3.84 \% \mathrm{SiO}_{2}$ and $1.50 \% \mathrm{Al}_{2} \mathrm{O}_{3}$ content, sample BD-2 of Bineda area contains $63.93 \% \mathrm{Fe}$ with $2.38 \% \mathrm{SiO}_{2}$ and $3.45 \% \mathrm{Al}_{2} \mathrm{O}_{3}$ content. In all, it has been observed that in the Bijawar region, as per IBM specifications only 3 samples of Nayakhera, Palda-Thakurpura and Bineda areas are of medium quality grade with marginal fluctuations in silica content, which can be easily separated by various separation techniques.

In addition, all the other samples of 8 study areas, have been found to contain Fe- content below $62 \%$ well within the prescribed limits of IMB for low grade quality ore. These samples also show slight variation in silica and alumina content. Hence worth, these samples having iron content below $62 \%$ cannot be opted for making steel.

It is worth mentioning here that, amongst 8 pointed areas of Bijawar, the areas like Palda-Thakurpura, Chopra, Bineda, Kalidhar areas totally lack high grade quality ore as they do not possess the requisite amount of Fe as per the specifications of IBM in the ore. Similarly, Siddai - Murar, Chopra, Kalidhar, Imiliya and Dilari areas lack medium grade quality ore.

\section{Geological Interpretation:-}

The iron ore deposits of Bijawar group are encompassed in ferruginous lithology. The main lithounit Karri formation is the source of these $\boldsymbol{F} \boldsymbol{e}$ deposits. The ore hematite is found in form of lumps concretions and nodules which seem to be a residual erosion product of parent ferruginous rocks. Thus, the iron (Fe) \% is high in these areas but they are highly variable. Thus it seems they may not succumb to systematic exploitation but may be used in up gradation of feed for steel making industries.

\section{Mahakoshal Region:-}

\section{Chemical Analysis and Interpretation:-}

Chemical analysis of samples of Mahakoshal group gave variable results in the 8 study areas namely Kochita, Jhoko, Bhainsahiya, Kosomhar, Charki, Umreha, Khaddi - Jamuniha \& Nimoura areas, which are tabulated in Table 5. The results shown in Table 5 clearly indicate that out of 8 study areas and 24 samples examined, sample JK-1 of Kochita area is found to content $56.60 \%$ iron content with $3.5 \% \mathrm{SiO}_{2}$ content and $8.90 \mathrm{Al}_{2} \mathrm{O}_{3}$ content, sample $\mathrm{K}-1$ of Khaddi-Jamuniha area is found to contain $51.40 \% \mathrm{Fe}$ content with $17.44 \% \mathrm{SiO}_{2}$ and $2.90 \% \mathrm{Al}_{2} \mathrm{O}_{3}$ content, sample 2 of Jhoko area is found to contain $48.96 \% \mathrm{Fe}, 23.24 \% \mathrm{SiO}_{2}$ and $2.12 \% \mathrm{Al}_{2} \mathrm{O}_{3}$ content while sample 4 of $\mathrm{Kosomhar}$ area contains $\mathrm{Fe}$ content $42.66 \%, \mathrm{SiO}_{2} 29.04 \%$ and $2.5 \% \mathrm{Al}_{2} \mathrm{O}_{3}$. While sample (Umrh-5 and Umrh-4) Umreha area Fe content $48.26 \%$ and $47.56 \%, \mathrm{SiO}_{2} 17.86 \%, 20.42 \%$ and $\mathrm{Al}_{2} \mathrm{O}_{3}$ about $2.50 \%$ and $3.40 \%$ respectively. About 7 samples of the studied areas have Fe content in the range 30-40\% while 3 samples viz. sample 1 of Jhoko area, sample 1 of Kosomhar area and sample 1 of Nimoura area showed Fe-content between 10-20\%. Quite striking results are observed in sample 1 of Kochita area with contains 5.94\% Fe-content, $2.00 \% \mathrm{Al}_{2} \mathrm{O}_{3}$, with quite high variation in $\mathrm{SiO}_{2} 81.46 \%$ and also sample 2 of Kosohmhar area showed Fe content to be $8.04 \%, \mathrm{Al}_{2} \mathrm{O}_{3} 2.00 \%$ with high fluctuation in $\mathrm{SiO}_{2}$ content $82.10 \%$. It is thus concluded that amongst 24 samples examined for 8 study areas in Mahakoshal region in accordance with IBM standards, none of the samples were found to be of high grade and medium grade quality. All the studied samples mentioned in Table 5 showed Fe-content in the ore to be less than $62 \%$, which is not upto the specification of good quality steel, making them low grade quality ore. 
Table 5:- Chemical Analysis of Iron ore samples of Mahakoshal Region.

\begin{tabular}{|c|c|c|c|c|c|c|}
\hline S. No & Name of the area & Sample code & $\mathrm{SiO}_{2} \%$ & $\mathrm{Fe}_{2} \mathrm{O}_{3} \%$ & $\mathrm{Fe} \%$ & $\mathrm{Al}_{2} \mathrm{O}_{3} \%$ \\
\hline \multirow[t]{4}{*}{1} & Kochita area & KC-1 & 81.46 & 8.50 & 5.94 & 2.00 \\
\hline & & JK-1 & 3.540 & 79.50 & 56.60 & 8.90 \\
\hline & & Jk-2 & 26.04 & 57.00 & 39.86 & 4.20 \\
\hline & & Average & 37.01 & 48.34 & 33.80 & 5.03 \\
\hline \multirow[t]{3}{*}{2} & Jhoko area & BS-1 & 55.12 & 32.50 & 20.98 & 5.36 \\
\hline & & BS-2 & 23.24 & 70.00 & 48.96 & 2.12 \\
\hline & & Average & 39.18 & 51.25 & 34.97 & 3.74 \\
\hline \multirow[t]{4}{*}{3} & Bhainsahiya area & $\mathrm{KCH}-1$ & 32.06 & 56.50 & 39.51 & 5.00 \\
\hline & & KCH-2 & 32.18 & 57.50 & 40.21 & 5.16 \\
\hline & & $\mathrm{KCH}-3$ & 24.88 & 63.50 & 44.41 & 3.26 \\
\hline & & Average & 29.70 & 59.16 & 41.38 & 4.47 \\
\hline \multirow[t]{5}{*}{4} & Kosomhar area & Kmsh-1 & 68.06 & 26.50 & 15.53 & 1.50 \\
\hline & & Kmsh-2 & 82.10 & 11.50 & 8.04 & 2.00 \\
\hline & & Kmsh-3 & 33.52 & 62.00 & 43.36 & 1.10 \\
\hline & & Kmsh-4 & 29.04 & 60.00 & 42.66 & 2.50 \\
\hline & & Average & 53.18 & 40.00 & 27.39 & 1.77 \\
\hline \multirow[t]{3}{*}{5} & Charki area & Chrk-1 & 10.36 & 70.00 & 48.96 & 4.70 \\
\hline & & Chrk-1 & 35.94 & 57.50 & 40.21 & 2.70 \\
\hline & & Average & 23.15 & 63.50 & 44.58 & 7.40 \\
\hline \multirow[t]{6}{*}{6} & Umreha area & Umrh-1 & 40.64 & 52.00 & 36.37 & 1.20 \\
\hline & & Umrh-2 & 39.90 & 54.00 & 37.77 & 2.00 \\
\hline & & Umrh-3 & 42.36 & 51.00 & 35.61 & 2.10 \\
\hline & & Umrh-4 & 20.42 & 68.00 & 47.56 & 3.40 \\
\hline & & Umrh-5 & 17.84 & 69.00 & 48.26 & 2.50 \\
\hline & & Average & 32.23 & 58.80 & 41.12 & 2.24 \\
\hline \multirow[t]{4}{*}{7} & Khaddi Jamuniha area & $\mathrm{K} 1$ & 17.44 & 73.50 & 51.4 & 2.90 \\
\hline & & $\mathrm{K} 2$ & 35.72 & 56.00 & 39.16 & 3.00 \\
\hline & & $\mathrm{K} 3$ & 39.5 & 55.00 & 38.46 & 3.60 \\
\hline & & Average & 30.88 & 61.50 & 43.00 & 3.16 \\
\hline \multirow[t]{3}{*}{8} & Nimoura area & NM-1 & 69.9 & 18.50 & 12.93 & 3.20 \\
\hline & & NM-2 & 42.94 & 52.00 & 36.97 & 2.30 \\
\hline & & Average & 56.42 & 35.25 & 24.65 & 2.75 \\
\hline
\end{tabular}


Diagrammatic representation of chemical analysis of Iron ore samples of Mahakoshal Region

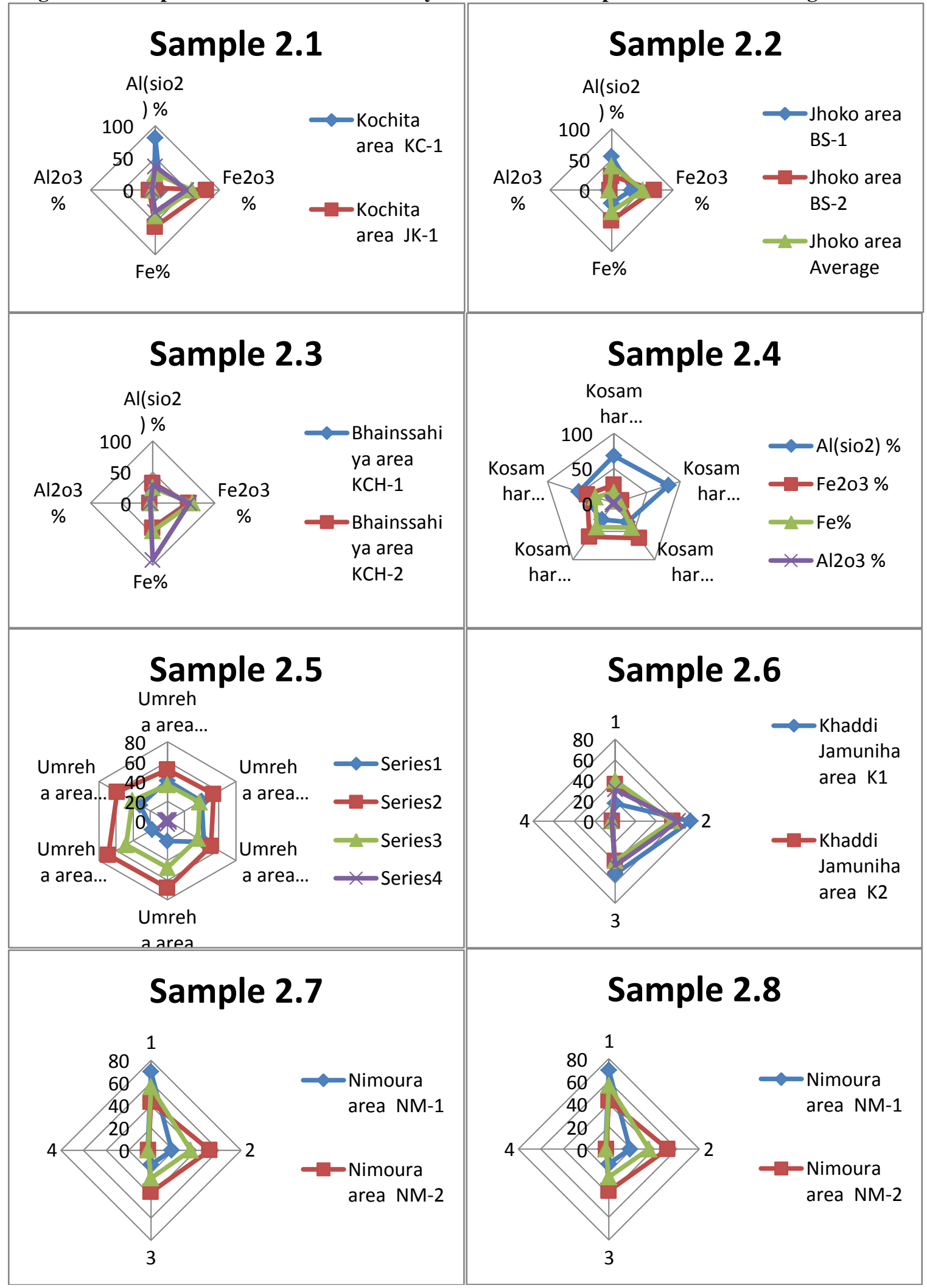




\section{Geological Interpretation:-}

The iron ore entity of Mahakoshal group encrusted in mainly BIF (BHQ/BHJ). It occupies central/ core portion of hill ranges the ore is mostly lumpy hematite but at places micaceous variety was also present. Further gradational changes from quartzite to BHQ are also evident in the area. In BIF, the quartzite fractions are dominating. Thus, silica is high and $\mathrm{Fe}$ is low, but due to uniform bedded nature of deposit, the deposit is suitable for systematic exploitation.

\section{Comparative study of Bijawar and Mahakoshal Region:-}

The comparative analysis of the two studied areas Bijawar and Mahakoshal region gave very interesting results, which could serve as a tool for further investigation and may prove beneficial for the industry.

In this comparative study 8 samples were investigated for both Bijawar and Mahakoshal regions. It has been deduced and thus interpreted from the results pointed in Table 6 that as per IBM standard specifications, none of the samples both in Bijawar as well as Mahakoshal regions were found to meet the requisite specifications for high grade quality ore.

It is to be noted that only one sample in the Bijawar group (sample 2) showed Fe-content to be $61.90 \%$ with $\mathrm{SiO}_{2}$ content $4.92 \%$ and $\mathrm{Al}_{2} \mathrm{O}_{3} 4.10 \%$, which is in marginal range to be medium grade quality ore. While all the other samples showed Fe-content ranging from $30 \%$ to $56 \%$, above $45 \%$ may be treated as beneficial quality ore.

Conversely, in the Mahakoshal region, samples showed Fe-content in the range $24.6 \%$ to $44.4 \%$ which is below the threshold value. Henceforth, does not meet the specific requirements of raw ore in industry to make better quality steel. It has also been visualized that Bijawar regions have higher Fe-content than that of Mahakoshal regions, suggesting the Bijawar region to be a better option than Mahakoshal regions for steel making.

Table 6:- Comparative Chemical Analysis of Iron ore samples of Bijawar and Mahakoshal Region.

\begin{tabular}{|c|c|c|c|c|c|c|c|c|c|}
\hline \multicolumn{9}{|c|}{ Bijawar Region } & \multicolumn{5}{c|}{ Mahakoshal Region } \\
\hline S.No & $\mathbf{A l}$ \% & $\mathbf{F e}_{\mathbf{2}} \mathbf{O}_{\mathbf{3}} \%$ & $\mathbf{F e \%}$ & $\mathbf{A l}_{\mathbf{2}} \mathbf{O}_{\mathbf{3}} \%$ & $\mathbf{S . ~ N o}$ & $\mathbf{A l} \%$ & $\mathbf{F e}_{\mathbf{2}} \mathbf{O}_{\mathbf{3}} \%$ & $\mathbf{F e \%}$ & $\mathbf{A l}_{\mathbf{2}} \mathbf{O}_{\mathbf{3}} \%$ \\
\hline 1 & 11.99 & 88.24 & 56.12 & 3.48 & 1 & 37.01 & 48.34 & 33.81 & 5.03 \\
\hline 2 & 4.920 & 88.50 & 61.90 & 4.10 & 2 & 39.18 & 51.25 & 34.97 & 3.74 \\
\hline 3 & 16.79 & 77.88 & 54.47 & 3.17 & 3 & 92.12 & 59.16 & 41.37 & 4.47 \\
\hline 4 & 12.62 & 79.62 & 55.72 & Traces & 4 & 53.18 & 40 & 28.14 & 1.77 \\
\hline 5 & 23.63 & 69.61 & 48.69 & 3.57 & 5 & 23.15 & 63.5 & 44.58 & 7.4 \\
\hline 6 & 17.2 & 68.23 & 30.88 & 7.93 & 6 & 32.23 & 58.8 & 41.12 & 2.24 \\
\hline 7 & 6.94 & 79.60 & 55.67 & 5.11 & 7 & 30.88 & 61.50 & 43.01 & 3.16 \\
\hline 8 & 22.64 & 63.47 & 44.39 & 6.07 & 8 & 56.42 & 35.25 & 24.65 & 2.75 \\
\hline Average & $\mathbf{1 4 . 5 9}$ & $\mathbf{7 6 . 8 9}$ & $\mathbf{5 3 . 7 4}$ & $\mathbf{4 . 1 7}$ & Average & $\mathbf{4 5 . 5 1}$ & $\mathbf{5 2 . 2 2}$ & $\mathbf{3 6 . 5 2}$ & $\mathbf{3 . 8 2}$ \\
\hline
\end{tabular}

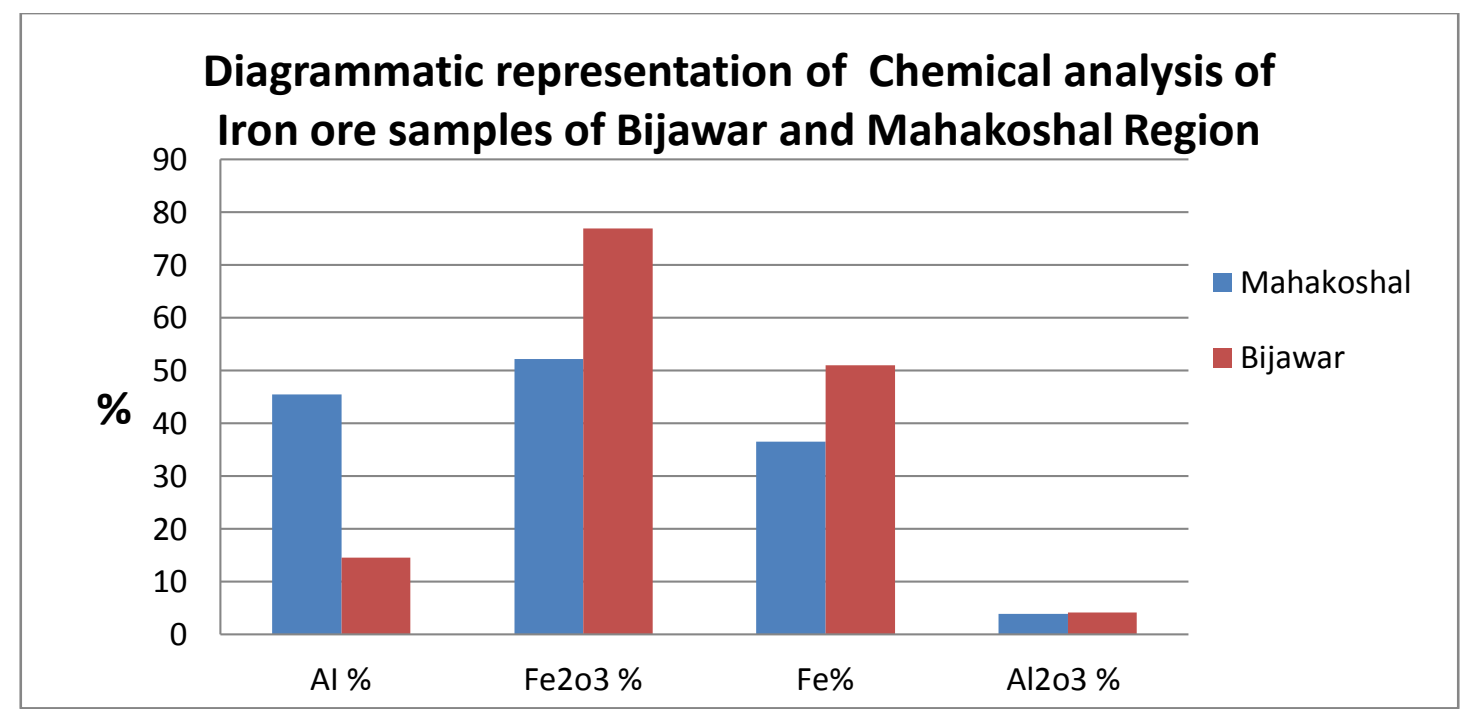




\section{Ratio of $\mathrm{Fe}_{2} \mathrm{O}_{3}$ and $\mathrm{SiO}_{2}$ in Ore Identification:-}

In order to assess the utility of steel, it is the \% content of $\mathrm{Fe}$ in the ore that plays the major role. But, at the same time, $\mathrm{SiO}_{2}$ and $\mathrm{Al}_{2} \mathrm{O}_{3}$ content in the ore cannot be ignored. Fluctuation in any of them may affect the quality of steel. If the content of $\mathrm{Si}$ and $\mathrm{Al}$ shows a marked increase compared to $\mathrm{Fe}$-content in the ore, it will affect the metal property and downgrade the ore, may not fulfill the specifications of IBM for making good quality steel.

To have a clear understanding of the influence of variations observed in $\mathrm{SiO}_{2}$ content with respect to $\mathrm{Fe}_{2} \mathrm{O}_{3}$, ratio of $\mathrm{Fe}_{2} \mathrm{O}_{3}$ and $\mathrm{SiO}_{2}$ are tabulated in nearly 8 samples of Bijawar and Mahakoshal region. It is thus predicted that if the $\mathrm{Fe}_{2} \mathrm{O}_{3} / \mathrm{SiO}_{2}$ ratio is found to be above 2.74 in the ore sample, the sample would lie in the Fe-ore category.

The above mentioned samples displayed in Table 7 were subsequently examined and results were accordingly interpreted. It has been observed that in the Bijawar region, nearly all samples showed $\mathrm{Fe}_{2} \mathrm{O}_{3} / \mathrm{SiO}_{2}$ ratio to be more that 2.74. On the contrary, in the Mahakoshal region, only one sample (Sample 5) showed $\mathrm{Fe}_{2} \mathrm{O}_{3} / \mathrm{SiO}_{2}$ ratio to be 2.74 , while all the other samples were below the range.

If we compare the two regions, overall Bijawar region on an average is showing $\mathrm{Fe}_{2} \mathrm{O}_{3} / \mathrm{SiO}_{2}$ ratio to be approximately 5, while Mahakoshal region ranges on an average to 1.14. Precisely, ore samples found in Bijawar region compound to Mahakoshal region could be more likely opted and utilized for making better quality steel.

Table 7:- Ratio of $\mathrm{Fe}_{2} \mathrm{O}_{3}$ and $\mathrm{SiO}_{2}$ in Iron ore samples of Bijawar and Mahakoshal Region.

\begin{tabular}{|c|c|c|c|c|c|c|c|}
\hline \multicolumn{9}{|c|}{ Bijawar Region } & \multicolumn{5}{c|}{ Mahakoshal Region } \\
\hline S. No & $\mathbf{F e}_{\mathbf{2}} \mathbf{O}_{\mathbf{3}} \%$ & $\mathbf{S i O}_{\mathbf{2}} \%$ & Factor & $\mathbf{S . ~ N o}$ & $\mathbf{F e}_{\mathbf{2}} \mathbf{O}_{\mathbf{3}} \%$ & $\mathbf{S i O}_{\mathbf{2}} \%$ & Factor $^{\mathbf{\%}}$ \% \\
\hline 1 & 88.24 & 11.99 & 7.35 & 1 & 48.34 & 37.01 & 1.30 \\
\hline 2 & 88.50 & 4.92 & 17.98 & 2 & 51.25 & 39.18 & 1.30 \\
\hline 3 & 77.88 & 16.79 & 4.63 & 3 & 56.16 & 92.12 & 0.60 \\
\hline 4 & 79.62 & 12.62 & 6.30 & 4 & 40.00 & 53.18 & 0.75 \\
\hline 5 & 69.61 & 23.63 & 2.94 & 5 & 63.50 & 23.15 & 2.74 \\
\hline 6 & 68.23 & 17.2 & 3.96 & 6 & 58.80 & 32.23 & 1.82 \\
\hline 7 & 79.60 & 6.94 & 11.46 & 7 & 61.50 & 30.88 & 1.99 \\
\hline 8 & 63.47 & 22.64 & 2.83 & 8 & 35.25 & 56.42 & 0.62 \\
\hline Average & $\mathbf{7 6 . 8 9}$ & $\mathbf{1 4 . 5 9}$ & $\mathbf{5 . 4}$ & Average & $\mathbf{5 2 . 2 2}$ & $\mathbf{4 5 . 5 2}$ & $\mathbf{1 . 7 4}$ \\
\hline
\end{tabular}

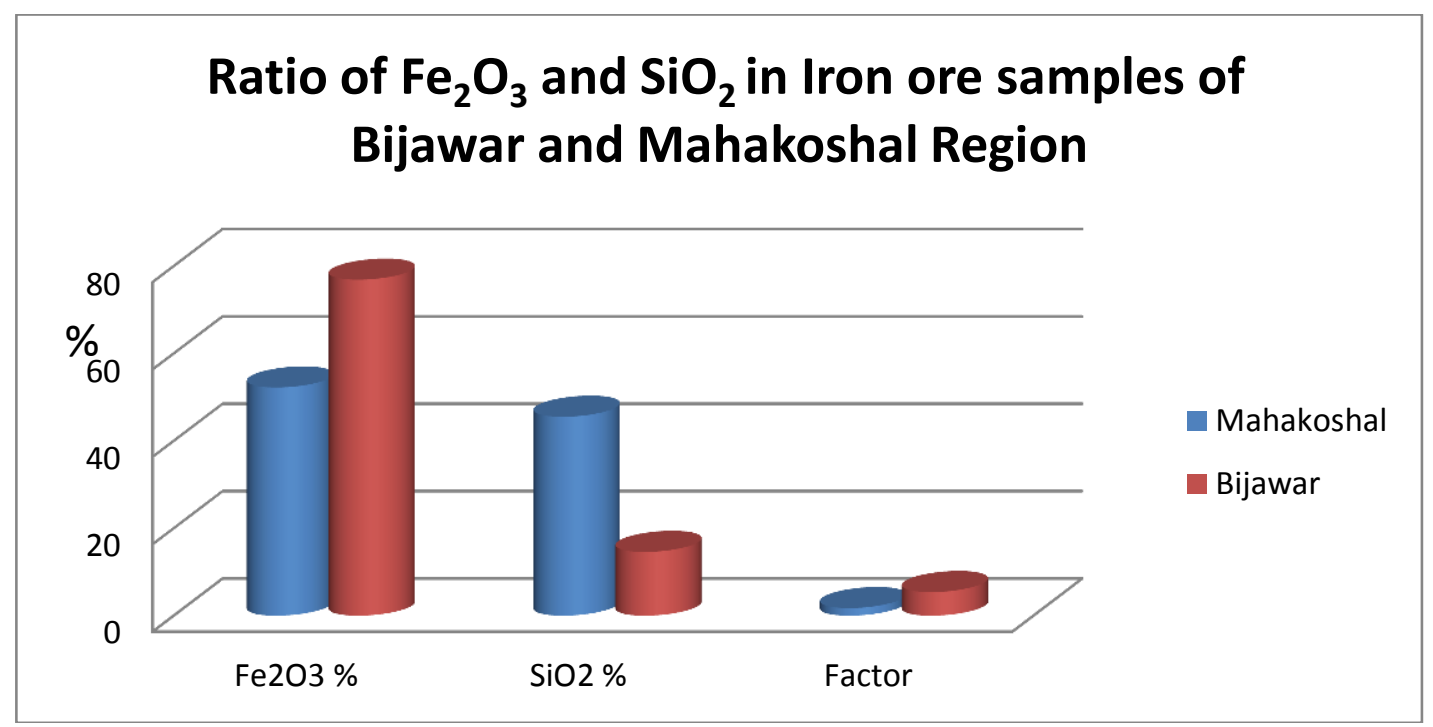

\section{Geological Interpretation:-}

The iron ore entity of Mahakoshal group are uniformed bedded) type where Fe \% is low but in general uniform which makes it easier to quantify where as iron ores of Bijawar group are erratic in nature when lumps and boulders of hematite occur. They can very well be used to upgrade the iron ores of Mahakoshal group to meet out the requirements of establishment of mineral based industry. 


\section{Observation:-}

If we compare $\mathrm{Fe}$ ore from Bijawar and Mahakoshal the first thing that strikes is the amount of Fe and the consistency of $\mathrm{Fe} \%$. The higher percentage and fluctuations of $\mathrm{Fe} \%$ in Bijawar group indicates that residual concentration processes of formation of iron ore entity whereas in Mahakoshal region low Fe \% indicates presence of bedded type of Fe ore bearing litho units where variation of ore is due to pinching and swelling of hematite bands in Banded iron formation (BHJ/BHQ).

\section{Conclusion:-}

In the present study, few areas of Bijawar and Mahakoshal regions were chosen to assess the iron, silica and alumina content in the form of their oxides. On chemical investigation of samples of Bijawar region, it has been found that some samples of Siddai-Murar area and Nayakhera area surpasses other areas of Bijawar region in having higher Fecontent, thus making them suitable for making quality steel. Mostly, samples of other areas of this region show quite variations in iron content, may be because this region bears Fe-ore in the form of lumps and nodules. On the other hand, the iron-ore deposits of Mahakoshal region are of uniform bedded nature, but have iron contents below the threshold value, the samples of this region could not meet the requirements of IBM for high grade and medium grade quality. Thus, was not found worthy enough for better productivity.

On comparison of iron-ore deposits of Bijawar and Mahakoshal regions, the authors have come to the conclusion that though iron-ores of Bijawar region are erratic in nature, and possess residual concentration of iron ore utility, the ores of this regions posses higher Fe content, and also $\mathrm{Fe}_{2} \mathrm{O}_{3} / \mathrm{SiO}_{2}$ factor lies in the limits of Fe-ore category. Whereas in samples of Mahakoshal region are uniformly bedded type, but possess low iron content and $\mathrm{Fe}_{2} \mathrm{O}_{3} / \mathrm{SiO}_{2}$ ratio is below the limits of Fe-ore category, So, ore samples of Bijawar regions may be more suited to cope up with the IBM standards for making quality steel, which could be beneficial both industrially and economically. Thus, the iron ores of Bijawar region may be used as sweetener to upgrade the iron ores of Mahakoshal region, which are low grade but may sustain systematic exploitation required for large scale mining operations.

\section{References:-}

1. B. D. Sparks and A. F. Sirianni, "Beneficiation of a phosphoriferous iron ore by agglomeration methods," International Journal of Mineral Processing, vol. 1, no. 3, pp. 231-241, 1974. View at Scopus.

2. Bett, A.K and Maranga, S. M (2012). Consideration for beneficiation of low Grade Iron Ore for steel Making in Kenya. Proceeding of the mechanical Engineering Conference on sustainable and innovation, 4, pp $263-267$

3. Burke, K.Victor, E. and Peane, K (2008). A Practical Guide for Preparation of Specimens for X-ray Fluorescence. Wiley-VCH, New York, pp 78-81

4. Central Pollution Control Board (2007), Comprehensive Document Series, "Comprehensive Industry Document on Iron Ore Mining"

5. Deer W A, Howie R A and Zussman J: An Introduction to the Rock Forming Minerals (2012) published by Mineralogical Society of great Britain and Ireland

6. Detailed Information Dossier (DID) of iron Ore in India @www.portal.gsi.gov.in

7. Dhopeshwar S. V. (2011): An unpublished report on "The Survey for Iron Ore Deposits in Hirapur Area, District Sagar, Chhatarpur and Damoh (M. P.), Field Season 2007-10

8. Dhopeshwar S. V. (2013). An unpublished Report on "Survey and Demarcation of Iron Ore Deposits in Sidhi District (M. P.),

9. End Use Grade Classification by Indian Bureau of Mines, www.gov.in, 2014

10. F. E. Katrak, "Iron and steel, future of," in Encyclopedia of Materials: Science and Technology, pp. 4292-4295, 2008.

11. Indian Mineral Yearbook by Indian Bureau of Mines (2014-15)

12. J. W. Guider, "Iron ore beneficiation key to modern steelmaking," Mining Engineering, vol. 33, no. 4, pp. 410-413, 1981. View at Scopus

13. K. Biswas, Principles of Blast Furnace Iron Making, SBA Publications, Calcutta, India, 2005.

14. Keru, G.K. (2011). Concentration of Iron in Murram (Laterite) from Ruiru Area, Thika District, Kenya to Asses Economic Viability. Department of Chemistry, Kenyatta University, Nairobi, M.Sc. Thesis.

15. Klein and Hurlbut, Manual of Mineralogy, 22nd Edition (1989).

16. Krishnaswamy, S, India's Mineral resources, $2^{\text {nd }}$ edition (1979) 
17. M. P. Srivastava, S. K. Pan, N. Prasad, and B. K. Mishra, "Characterization and processing of iron ore fines of Kiruburu deposit of India," International Journal of Mineral Processing, vol. 61, no. 2, pp. 93-107, 2001. View at Publisher · View at Google Scholar. View at Scopus

18. M. S. Dobbins and G. Burnet, "Production of an iron ore concentrate from the iron-rich fraction of power plant fly ash", Resources and Conservation, vol. 9, pp. 231-242, 1982. View at Scopus

19. Parbin Singh, Engineering \& General geology, $4^{\text {th }}$ Edition, By Katson Publishing House (1978)

20. Platts, "Methodolgy and Specification Guide: Iron Ore", The McGraw.Hill, Companies,2010, http:// www. platts. com/ IM. Platts. Content/ Methodology References/ Methodology Specs/ ironore.pdf.

21. R. Semukaaya, Characterisation of Muko Iron Ore Deposits for Iron and Steel Production, Makerere University Library, Kampala, Uganda, 2007.

22. Read, H.H. 'Rutley's Elements of Mineralogy', published by Thomas Murby \& Co, London (1976)

23. Svoboda, J. (1987) Magnetic methods for the treatment of minerals Amsterdam, Elsevier. Pp648-

24. The Statistica Portal @www.statistica.com, (2015)World resources of iron Ore by country

25. Threshold value of minerals for implementation by Indian Bureau of Mines, Govt. of India, Ministry of Mines (2009)

26. U. Scwertmann and R. M. Cornell, Iron Oxides in the Laboratory, Preparation and Characterisation, WileyVCH, Weinheim, Germany, 2000.

27. U. Scwertmann and R. M. Cornell, The Iron Oxides, Structure, Properties, Reactions, Occurrences and Uses, Wiley-VCH, Weinheim, Germany, 2006.

28. USGS Mineral Information: iron ore, USGS Publication(2013, 2015), Annual Publication. 